\section{Turning a phrase to advantage}

\section{Alan Brafield}

An Urchin in the Storm: Essays About Books and Ideas. By Stephen Jay Gould. W.W. Norton: 1987. Pp. 255. \$18.95.

A RECENT review in these columns of a book entitled Communicating Science to the Public pointed out that the symposium it reflected had contained no contributions from the "great popular communicators" or, indeed, from any scientists. The reviewer also quoted Rutherford's dictum that "no theory was to be taken seriously that could not be explained to a barmaid". Whether Rutherford meant this as a slur on one of my favourite groups of people or as a compliment is a matter for argument, but there is no doubt that popularizing science effectively is as difficult as it is necessary. Gould, one of the very best popularizers, has now produced the latest of his more or less biennial collections of essays. This one is different in that it is a collection of book reviews, but the format and often the content are in the familiar mould.

In the preface, Gould maintains that book reviews need not be ephemeral, and contrasts the pedantic and parochial account of a work's content and merit with the type of review in which the writer uses the book's main thrust as an anchor for discussing an issue of wider scope. Naturally he prefers the latter, and says that he cherishes a perceptive essay on embryology and evolution by J.Z. Young although it only mentioned at the end his own book (Ontogeny and Phylogeny) which was the reason for writing the piece. An Urchin in the Storm contains 18 essays, written over the past decade, all but one of which originally appeared in The New York Review of Books. Gould writes: "We must believe that books, and their ideas, have an enduring meaning worth consideration after an actual title goes out of print". (In fact the latest edition of Books in Print shows that all 23 titles he considers are still available.)

The customary flair and insight are well in evidence and the book is a pleasure to read. I have no wish to pass a long future "in the jaws of Satan", a fate pictured by Gould for several reviewers of his books, but I have two misgivings about this one. First, readers familiar with Gould's writings will feel a definite sense of déjà $v u$, for we are well aware of his limited regard (to put it mildly) for reductionism, intelligence testing, pop-sociobiology, adaptationism and so on, and we know he objects strongly to the non-reporting of null results (he and Eldredge proposed the theory of punctuated equilibrium "to grant stasis in phylogenetic lineages the status of "worth reporting'"). Secondly, he attacks some authors so unmercifully and relentlessly that one feels sorry that they can exercise no right of reply.

The lucidity of his arguments and the ease of his writing are as remarkable and satisfying as ever. $\mathrm{He}$ is like his avian namesake the jay, colourful and garrulous. Every so often comes one of those finely turned phrases (which P.G. Wodehouse also revelled in and called his "nifties"). For example, "the success of one field after a painfully slow beginning does not guarantee that all disciplines in a similar state have a rosy future; as with species and businesses, most never get very far". Or, "although stomping dinosaurs cannot make continents drift, organisms do create and shape their environment; they are not billiard balls passively buffeted about by the pool cues of natural selection". The essays are arranged in five sections, not very convincingly in some cases in spite of the lengthy justification for the groupings in the preface. The one containing sympathetic but lively sketches of "four biologists" (Barbara McClintock, E.E. Just, G. Evelyn Hutchinson and Lewis Thomas) is particularly delightful.

The title is typically Gould. Urchin is an old name for a hedgehog and his startingpoint is the aphorism attributed to Archilochus that "the fox knows many things but the hedgehog knows one big thing". The way of the hedgehog is "coherence". He balls up and presents his spines to the world but can also (though only in legend) aim his darts. Gould is happy to see

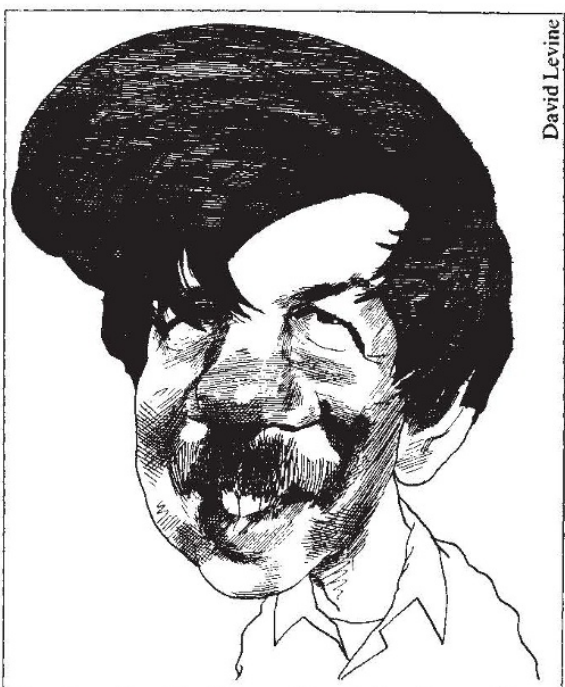

Stephen Jay Gould -- colourful and garrulous.

himself in this role and to show other traits of hedgehoggery. The storm is the plethora of scientific information and the controversy and complexity it involves. As I write there is a series of letters in The Times noticing that some hedgehogs keep going when they sense an approaching vehicle and so escape, rather than balling up and getting squashed, and that these smarter hedgehogs are becoming more common (as a biologist would expect). I don't know which type Gould would identify with but he is quite capable of turning at the last moment to squash any runaway ideological juggernaut.

Alan Brafield is in the Department of Biology, King's College London (KQC), University of London, Campden Hill Road, London W8 $7 A H, U K$.

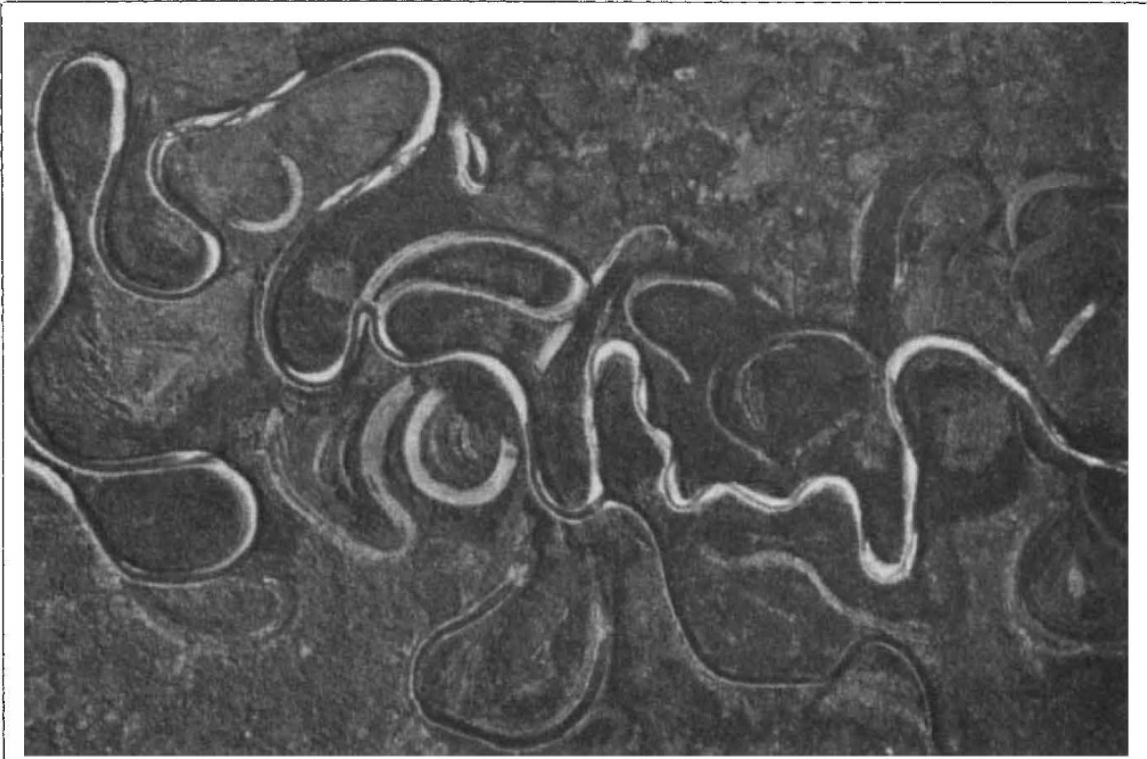

Winding down - the Hay River in Alberta, Canada, showing meanders, cutoffs, oxbow lakes, swamps and floodplain. The photograph, taken at about $6 \mathrm{~km}$, is from the $3 r d$ edition of Modern Physical Geography by Arthur N. Strahler and Alan H. Strahler. The new edition has increased coverage of subjects of current importance such as remote sensing and plate tectonics, as well as environmental topics including the impacts of acid rain and environmental carbon dioxide, and the destruction of low-latitude rainforests. The book is published by John Wiley, price $£ 31.80$, \$34.65; Wiley International Edition (for students) £14.95, \$11.95. 